\title{
Synchrotron imagery of phosphatized eggs in Waptia cf. W. fieldensis from the middle Cambrian (Miaolingian, Wuliuan) Spence Shale of Utah
}

\author{
Justin Moon, ${ }^{1,2 *}$ (D) Jean-Bernard Caron, ${ }^{1,2,3}$ and Robert R. Gaines ${ }^{4}$ \\ ${ }^{1}$ Department of Ecology and Evolutionary Biology, University of Toronto, 25 Willcocks Street, Toronto, Ontario, M5S 3B2, Canada \\ $<$ justin.moon@mail.utoronto.ca $>,<$ jcaron@rom.on.ca> \\ ${ }^{2}$ Department of Natural History, Royal Ontario Museum, 100 Queen's Park, Toronto, Ontario M5S 2C6, Canada \\ ${ }^{3}$ Department of Earth Sciences, University of Toronto, 22 Russell Street, Toronto, Ontario M5S 3B1, Canada \\ ${ }^{4}$ Geology Department, Pomona College, 185 E. Sixth Street, Claremont, California 91711, USA <robert.gaines@ pomona.edu>
}

\begin{abstract}
Exceptionally preserved fossil eggs and embryos provide critical information regarding paleoembryogenesis, reproductive strategies, and the early ontogeny of early arthropods, but the rarity of preservation of both eggs and egg-bearing organisms in situ limits their use in detailed evolutionary developmental (evo-devo) studies. Burgess Shale-type deposits preserve rare instances of egg-bearing arthropods as carbonaceous compressions; however, the eggs are usually poorly preserved with no compelling evidence of embryos. We describe the first record of a brooding specimen of Waptia cf. W. fieldensis from the Spence Shale, a Cambrian (Wuliuan Stage) Burgess Shale-type deposit in northeastern Utah and southeastern Idaho. This is the first record of an egg-bearing arthropod from the Spence Shale and it exhibits two distinct modes of preservation among eggs within the single clutch: carbonization and phosphatization. Unlike the egg-bearing Burgess Shale specimens, many eggs of this Utah specimen are also preserved three-dimensionally. In addition, synchrotron radiation X-ray tomographic microscopy reveals internal distributions of mineral phases, along with potential remnants of the egg membrane and attachment structures, but, as in the Burgess Shale, no explicit traces of developing embryos. The distinct modes of preservation highlight the existence of diagenetic microenvironments within some eggs, but not in others during fossilization.
\end{abstract}

\section{Introduction}

Exceptionally preserved eggs and embryos from the Cambrian period provide important biological information on the ontogeny, embryogenesis, and reproductive strategies of early arthropods (e.g., Zhang and Pratt, 1994; Duan et al., 2014; Caron and Vannier, 2016; Ou et al., 2020), scalidophorans (e.g., Donoghue et al., 2006a; Zhang et al., 2011), and cnidarians (e.g., Dong et al., 2013; Han et al., 2013); yet, it is only under exceptional conditions that fossilization of eggs and embryos can occur (Bengtson and Zhao, 1997; Donoghue et al., 2006b; Gostling et al., 2008; Briggs and McMahon, 2016).

In Paleozoic deposits, early metazoan eggs are most commonly preserved via phosphatization, which is an important taphonomic pathway that may lead to exceptional threedimensional preservation of the ultrastructural details of labile, non-biomineralizing structures found in eggs and embryos (Allison, 1988a; Bengtson and Zhao, 1997; Donoghue et al., 2006b; Dornbos, 2011; Muscente et al., 2015). Other taphonomic

\footnotetext{
*Corresponding author
}

pathways resulting in the preservation of eggs include pyritization (e.g., Siveter et al., 2014; Hegna et al., 2017; Ou et al., 2020), calcification (e.g., Martin et al., 2003), silicification (e.g., Lin et al., 2006; Muscente et al., 2015), or a combination of these modes. Although many fossilized marine metazoan eggs and embryos are reported solely from isolated eggs (e.g., Donoghue et al., 2006a; Dong et al., 2013; Han et al., 2013), in rare cases, eggs can also be preserved with the egg-producing organism as carbonaceous compressions, which is a mode of preservation characteristic of Cambrian Burgess Shale-type (BST) deposits (Butterfield, 2003; Gaines et al., 2008; Gaines, 2014; Schiffbauer et al., 2014) that presents undeniable evidence of the adult animals responsible for egg production (e.g., Duan et al., 2014; Hegna et al., 2017). In the Burgess Shale, only Waptia fieldensis Walcott, 1912, is currently known to preserve egg clutches, but, unfortunately, as in other Cambrian BST deposits known to preserve eggs (e.g., Lin et al., 2006; Duan et al., 2014; Ou et al., 2020), ultrastructural evidence of the developing embryos has remained equivocal (Caron and Vannier, 2016).

Here we report the first discovery of exceptionally preserved eggs from the Cambrian Spence Shale in Utah. The eggs are preserved in situ as a clutch in a specimen of arthropod 
that we identify as Waptia cf. W. fieldensis. As is typical in other BST deposits, the body of Waptia is preserved twodimensionally as a carbonaceous compression, although many of the eggs retain some three-dimensionality. The threedimensional preservation of some eggs allows us to use a combination of analytical techniques, including EDS elemental analysis and synchrotron radiation $\mathrm{X}$-ray tomographic analysis (SRXTM), to investigate the morphology of the eggs, to search for possible internal or ultrastructural features, and to constrain their taphonomic history. SRXTM, micro CT-scanning, and similar computed tomographic imaging have been favored over the last two decades for the study of fossil eggs and embryos in particular (e.g., Donoghue et al., 2006a; Cheng et al., 2011; Siveter et al., 2014; Ou et al., 2020). These methods not only provide a non-destructive alternative to imaging fossil specimens in a three-dimensional space, but also have the potential to produce high resolution images of key ultrastructural details that normally cannot be detected using traditional microscopic techniques (Stampanoni et al., 2002; Donoghue et al., 2006a; Sutton, 2008; Cheng et al., 2011; Siveter et al., 2014; Eriksson et al., 2016; Yin et al., 2016).

\section{Geological setting}

The middle Cambrian (Miaolingian Series; Wuliuan Stage) Spence Shale Member of the Langston Formation is exposed in northeastern Utah in the Wellsville Mountains and Wasatch Range, and in southeastern Idaho in the Bear River Range. The Spence Shale Member is assigned to the Albertella and Glossopleura trilobite biozones, between the underlying Naomi Peak Limestone Member and the overlying High Creek Limestone Member (Liddell et al., 1997; Garson et al., 2012; Kimmig et al., 2019; Whitaker et al., 2020). Flooding of the continent during the Cambrian resulted in establishment of three prominent facies belts on the passive margin, including inner and outer detrital clastic belts, divided by shallow water carbonate platform facies. The Spence Shale Member represents deposition at the edge of the outer detrital belt, across a ramp that descended from a carbonate platform (Foster and Gaines, 2016; Kimmig et al., 2019). This transition is well captured in a series of exposures across the western front of the Wellsville Mountains, where the Miners Hollow locality, from which the specimen was collected, represents one of the more distal exposures of the Spence Shale Member in the Wellsville Mountains (Liddell et al., 1997; Briggs et al., 2008; Garson et al., 2012; Hammersburg et al., 2018; Kimmig et al., 2019; Whitaker et al., 2020). There, the mudstone-dominated unit is comprised of mixed siliciclastic and carbonate facies and comprised of at least six meter-scale parasequences that show evidence for upward shallowing (Liddell et al., 1997; Kloss et al., 2015; Whitaker et al., 2020).

Despite the rarity of exceptional preservation, continuous survey efforts at the Spence Shale by amateur collectors-the Gunther family, Phil Reese, and Paul Jamison (Whitaker and Kimmig, 2020) — have provided many excellent specimens of both biomineralizing fauna (e.g., polymerid trilobites, brachiopods, echinoderms, hyolithids, agnostids) (Babcock and Robison, 1988; Gaines and Droser, 2005; Briggs et al., 2008;
Conway Morris et al., 2015; Foster and Gaines, 2016; Kimmig et al., 2019) and soft-bodied biotas (Robison, 1969; Rigby, 1980; Conway Morris and Robison, 1988; Robison et al., 2015; Foster and Gaines, 2016; Kimmig et al., 2019), including enigmatic forms (e.g., Kimmig and Selden, 2020). In addition to body fossils, abundant trace fossils are preserved within bioturbated intervals, suggesting fluctuations in bottom-water oxygenation that were periodically conducive to colonization by benthic communities (Garson et al., 2012; Kimmig and Strotz, 2017; Hammersburg et al., 2018). Miners Hollow has thus far yielded the greatest diversity of soft-bodied taxa (20 species) in the Spence Shale (Kimmig et al., 2019).

\section{Material and methods}

The Waptia cf. W. fieldensis Walcott, 1912, specimen (KUMIP 314032) (Figs. 1.2, 1.3, 2.4-2.7) was collected by the Gunther Family at Miners Hollow (Sec. 14, T10N, R02W; $41.6023^{\circ} \mathrm{N}, 112.0334^{\circ} \mathrm{W}$ ), Wellsville Mountains, Langston Formation, Spence Shale, Utah, United States (Kimmig et al., 2019, p. 610, fig. 1). The specimen was photographed with a Canon EOS 5D Mark II (f/6.3, 1/100 sec, ISO $2500,100 \mathrm{~mm}$ focal length) using different illumination techniques (Fig. 1). Dimensions of eggs were measured using Dragonfly version 2021.1 for Windows (Object Research Systems (ORS) Inc., 2021), where max length and diameter measurements were taken from the dorsal point of view to keep the orientation consistent (Table 1). Portions of eggs cropped out of the synchrotron images were estimated based on Figure 2.7 using FIJI ImageJ software for Windows (Schindelin et al., 2012). Synchrotron images were taken at beamline ID 19 of the European Synchrotron Radiation Facility, Grenoble, France, to investigate the ultrastructural details of the eggs. One of the eggs (referred to as Egg One) (Figs. 1.7, 3) became loose and was analyzed separately from the matrix. Egg One was imaged using $26.5 \mathrm{keV}$ monochromatic beam at $0.65 \mu \mathrm{m}$ resolution. All other eggs were scanned using $110 \mathrm{keV}$ monochromatic beam at $0.64-0.66$ $\mu \mathrm{m}$ resolution. Synchrotron images were converted from .TIFF to grayscale .JPEG using the FIJI ImageJ software for Windows (Schindelin et al., 2012) batch convert tool to accommodate hardware limitations. The converted data were volume-rendered in Dragonfly version 2021.1 (Object Research Systems (ORS) Inc., 2021). All eggs were segmented by: (1) enforcing contrast thresholds to isolate the fossils from the matrix (Fig. 4.2, 4.3); (2) creating regions of interest; and (3) applying false colors for segmentation (Fig. 4.4). Backscatter Electron image (BSE) and Energy-dispersive $\mathrm{X}$-ray spectroscopy (EDS) was conducted on a single isolated egg (Egg One) using a FEI Quanta 200 FEG Environmental SEM, with an EDAX Octane Plus SDD x-ray detector in Low Vacuum mode with chamber pressure of $70 \mathrm{~Pa}$ to analyze the surface composition of Egg One at 80x magnification with a scanning energy of $12 \mathrm{kv}$ at the University of Windsor, Toronto, Canada. The single egg initially had been glued using cyanoacrylate on a toothpick for analysis at the synchrotron. Some residues of cyanoacrylate could not be removed, which explains local concentrations of carbon. 

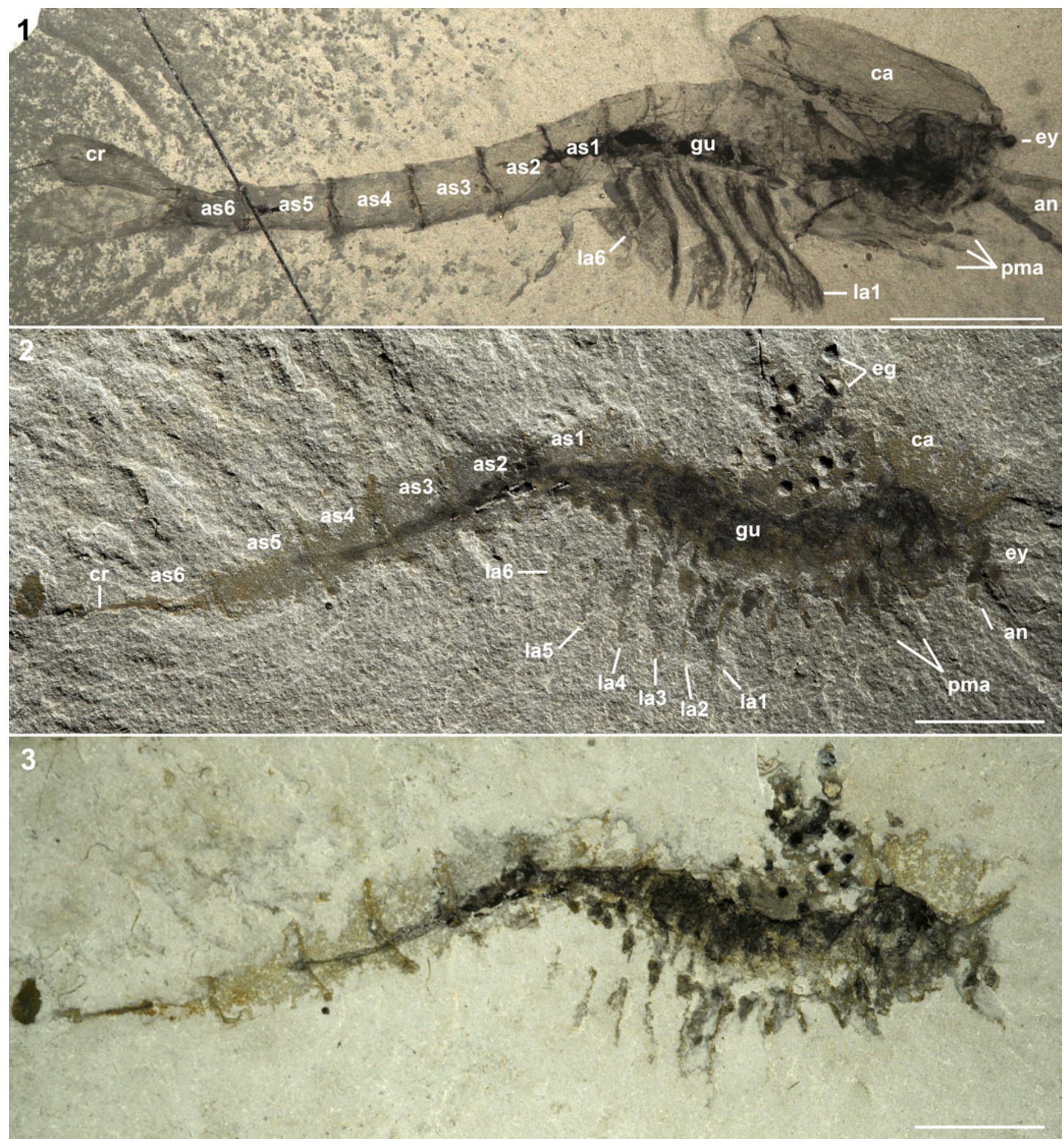

Figure 1. (1) Waptia fieldensis (USNM 114259) from the Burgess Shale, middle Cambrian, Yoho National Park, British Columbia, Canada (Caron and Vannier, 2016, p. 70, fig. 1A), lateral view of the body preserved as a carbonaceous compression under high-angle cross-polarized lighting. (2) Waptia cf. W. fieldensis (KUMIP 314032) from the Langston Formation, Spence Shale Member, middle Cambrian, Miners Hollow, Wellsville Mountains, Utah, United States, lateral view under low-angle incidental lighting showing the identifiable morphological features, and the egg cluster located antero-dorsal to the specimen; (3) same as (2), but taken underwater with high-angle, polarized lighting. Abbreviations: an $=$ antennule, as $1-\mathrm{as} 6=1^{\text {st }}$ to $6^{\text {th }}$ abdominal segments, ca $=$ carapace, $c r=c a u d a l$ rami; eg $=$ eggs, ey $=$ eye, gu $=$ gut, la $1-\mathrm{la} 6=1^{\text {st }}$ to $6^{\text {th }}$ post-cephalothoracic lamellate appendages, pma $=$ post-maxillular cephalothoracic appendage. All scale bars represent $1 \mathrm{~cm}$

Repository and institutional abbreviation.-The specimen is deposited at the Division of Invertebrate Palaeontology, Biodiversity Institute and Natural History Museum (KUMIP), University of Kansas, Lawrence, Kansas, U.S.A.

\section{Results}

Morphological description.-The specimen KUMIP 314032 (part and counterpart, Figs. 1.2, 1.3, 2.4, 2.5) consists of a 

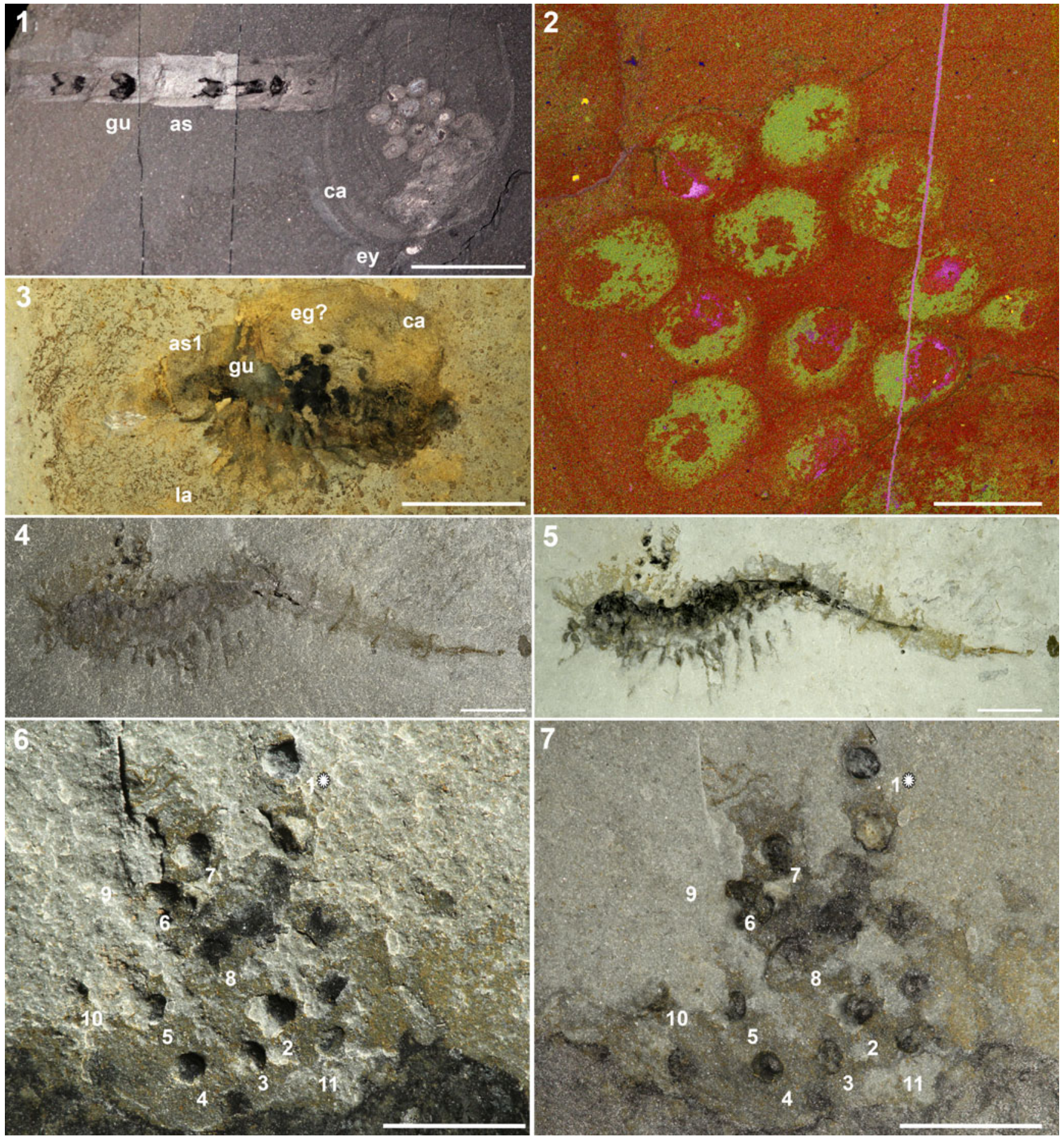

Figure 2. (1, 2) Waptia fieldensis (ROM 63354) from the Burgess Shale, middle Cambrian, Yoho National Park, British Columbia, Canada (Caron and Vannier, 2016, p. 71, fig. 2C); (1) lateral preservation showing egg cluster preserved underneath carapace under high-angle incidental lighting; (2) close up of egg cluster in (1) as a phase map showing differential preservation of the inner section and outer section of the eggs (Caron and Vannier, 2016, p. 71, fig. 2D). Arrows indicate inner areas representing carbon, calcium, and sulfur. The brighter areas surrounding the arrows represent aluminum and potassium. (3) Waptia cf. W. fieldensis (KUMIP 314044) from the Langston Formation, Spence Shale Member, middle Cambrian, Cataract Canyon, Wellsville Mountains, Box Elder County, Utah, United States (e.g., Briggs et al., 2008, p. 251, fig. 12.3), right-lateral view showing potential egg cluster located on the anterior of the incomplete specimen; (4) counterpart of Waptia cf. W. fieldensis (KUMIP 314032) from the Langston Formation, Spence Shale Member, middle Cambrian, Miners Hollow, Wellsville Mountains, Utah, United States, lateral view of body fossil and egg cluster located anterior-dorsal to the body under high-angle incidental lighting; (5) same as (4), but taken underwater with high-angle cross-polarized lighting; (6) close-up of egg cluster from Figure 1.2, showing locations of three-dimensionally preserved eggs (1-11) and eggs preserved as carbonaceous compressions (no numbers) under low-angle incidental lighting. Egg One (1*) was removed from the host rock and analyzed separately. Egg Nine is within the host rock and was identified from synchrotron data. Lightbulb indicates the source of incident light, which illuminated Egg One with positive relief prior to removal; (7) view of (6) under cross-polarized lighting. Abbreviations: as $=$ abdominal segments, as $1=1^{\text {st }}$ abdominal segment; ca $=$ carapace, eg $=$ eggs, eg? = possible egg preservation; ey = eye, gu $=$ gut, la = post-cephalothoracic lamellate appendages. Scale bars $=1 \mathrm{~cm}(\mathbf{1}, \mathbf{3}, \mathbf{4}, \mathbf{5}) ; 2 \mathrm{~mm}(\mathbf{2}) ; 5 \mathrm{~mm}(\mathbf{6}, 7)$. 
Table 1. Approximate egg diameter measurements ( $\mathrm{mm}$ ) of Waptia $\mathrm{cf}$. W. fieldensis (KUMIP 314032) from the Spence Shale. Dimensions were measured from synchrotron data. * indicates estimated dimensions based on a combination of cropped synchrotron images and Figure 2.7.

\begin{tabular}{lcc}
\hline Egg Number & Egg Diameter & Average Egg Diameter \\
\hline 1 & 1.00 & \\
2 & 1.10 & \\
$3^{*}$ & 0.99 & \\
4 & 0.96 & \\
$5^{*}$ & 0.56 & \\
$6^{*}$ & 1.08 & \\
7 & 1.03 & \\
$8^{*}$ & 0.91 & \\
9 & 0.93 & 0.96 \\
10 & 1.20 & \\
11 & 0.84 & \\
\end{tabular}

single specimen that is preserved laterally as a flat carbonaceous compression. The body is incompletely preserved, showing outlines of abdominal segments, eyes, appendages, carapace, gut traces, and an egg cluster that is partially preserved on both part and counterpart. The body is elongate with three clear tagmata: (1) the anterior region bears a pair of eyes and what appears to be the remnants of antennules and post-maxillular appendages; (2) the middle region bears six pairs of post-cephalothoraxic appendages, although few details are preserved; and (3) the posterior region is characterized by six limbless ring-shaped segments and what appear to be the remnants of caudal rami. There is also a gut trace that runs centrally along the ventral side of the abdominal segments and cephalothorax. Although the carapace is not well preserved, it appears to encapsulate most of the anterior of the cephalothorax. Overall, these morphological characteristics are consistent with waptiid arthropods (Hymenocarina), in particular Waptia fieldensis from the Burgess Shale (Vannier et al., 2018). Since many morphological structures are poorly preserved, including the caudal rami, premaxilla, and antennules, this specimen is herein considered as Waptia cf. W. fieldensis. Two other specimens of Waptia $\mathrm{cf}$. W. fieldensis that show a similar type of preservation are also known from Cataract Canyon, which is another related Spence Shale locality just a few kilometers south of Miners Hollow (Fig. 2.3; Briggs et al., 2008, p. 251, fig. 12.3). One of them, the counterpart of KUMIP 314038 (Fig. 2.3), which was not figured in Briggs et al. (2008), shows darker structures below the carapace that are consistent with eggs, but are poorly preserved compared to the structures observed in KUMIP 314032 and are not discussed further.

Total preserved body length from the eyes to the tip of the caudal ramus reaches $7.8 \mathrm{~cm}$. An egg cluster of $\sim 18$ eggs in total is preserved dorso-laterally to the body. Eleven eggs are preserved more or less three-dimensionally, one of which (referred to as Egg Nine) (Fig. 2.6, 2.7) is preserved entirely within the matrix and was only revealed using SRXTM. At least another seven eggs are preserved as dark compressions and appear flattened (Fig. 2.6, 2.7). The three-dimensionally preserved eggs are mostly round or ovoid in shape. These eggs are located both near and distal to the cephalothorax dorsally (Fig. 1.3, 1.4). The eggs of $W$. cf. W. fieldensis reach an average of $0.96 \mathrm{~mm}$ in diameter (Table 1), although precise measurements are difficult to obtain due to variations in the degree of preservation (i.e., highly compacted eggs may not reflect the original egg size, thus inflating the measurement). Most eggs appear to be more or less equidistant from each other, average distance of $2 \mathrm{~mm}$, except Egg One, which is most distally positioned (Fig. 2.6, 2.7).

Taphonomic description.-Comparisons between the optical image of the three-dimensionally preserved Egg One and elemental maps suggest that the darker zones seen on the optical image along the surfaces of the egg correspond to zones of enrichment in $\mathrm{Ca}$ and $\mathrm{P}$ (Fig. 3). Overall, the surface of the egg is also rich in $\mathrm{Al}, \mathrm{Si}$, and $\mathrm{K}$, but is similar to the matrix in the relative abundance of these elements. Higher concentrations of carbon along the margins of the egg represent an artefact (see material and methods), also clearly seen on the secondary electron image. Although $\mathrm{Mg}$ and $\mathrm{Fe}$ show very low concentrations overall, Fe is concentrated along the margin of the egg and in the sediment matrix. Localized concentrations of $\mathrm{S}$ and $\mathrm{Ba}$ correspond to surficial bright phases visible on the BSE image (Fig. 3) and suggest the presence of barite crystals at the surface of the egg.

Synchrotron imagery of the egg cluster revealed two primary phases with different X-ray densities (Fig. 4.1; Supplementary Data 1). Denser materials are shown as bright white clusters and less-dense materials are gray in color. Analyzed individually and at higher resolution, eggs show distinct internal mineral fillings (Fig. 4.2-4.4; Supplementary Data 2). The most prominent phase is low-contrast and heterogeneous in texture. Another phase, presumably pyrite crystals, based on cubictriangular outlines of individual crystals, is represented by tiny bright spots dispersed throughout the matrix and within the inner egg space. Pyrite is locally more abundant inside the eggs than in the matrix, and the amount of pyrite is variable among the eggs analyzed (Fig. 4.1).

Three eggs (Egg One, Egg Four, and Egg Nine) show potential evidence of egg ultrastructure (Fig. 4.5-4.7). Egg One is elliptical in shape and has an irregular trailing edge on one side of the egg, which could represent the site of attachment to the carapace (Fig. 4.3, 4.4), although this feature is clearer in Egg Nine (Fig. 4.7). In Egg One, the heterogeneous phase occupies the majority of the internal space with pyrite concentrated mostly in the other quarter to third of the egg space (Fig. 4.2-4.4). Egg Four is rounded and has a smooth surface (Fig. 4.5). In contrast to Egg One, the internal egg space does not appear to be homogenous and exhibits conspicuous dark patches. Only Egg Four exhibits a thickened external wall-like structure, which ranges between 9-11 $\mu \mathrm{m}$ in thickness, and unlike the mottled texture of the inner egg space, it is homogeneous in texture, and clearly delineates the outer matrix from the inner egg space (Fig. 4.5, 4.6). However, the wall-like structure does not completely encapsulate the egg and appears to have partially decayed. Additionally, the matrix immediately surrounding the egg shows a different texture from the outlying matrix, which may suggest the presence of an accessory egg structure, such as a jelly coat, comparable to those found in extant marine invertebrates (Fig. 4.5; Martin et al., 2005, p. 569, fig. 5A). Egg Nine appears to be greatly decayed, having comparable inner texture to Egg Four, and having larger pyrite crystals within it (Fig. 4.7). Additionally, there are features within the egg that appear as dark lines of $\sim 1 \mu \mathrm{m}$ in thickness and bisect larger internal features (Fig. 4.7). These 

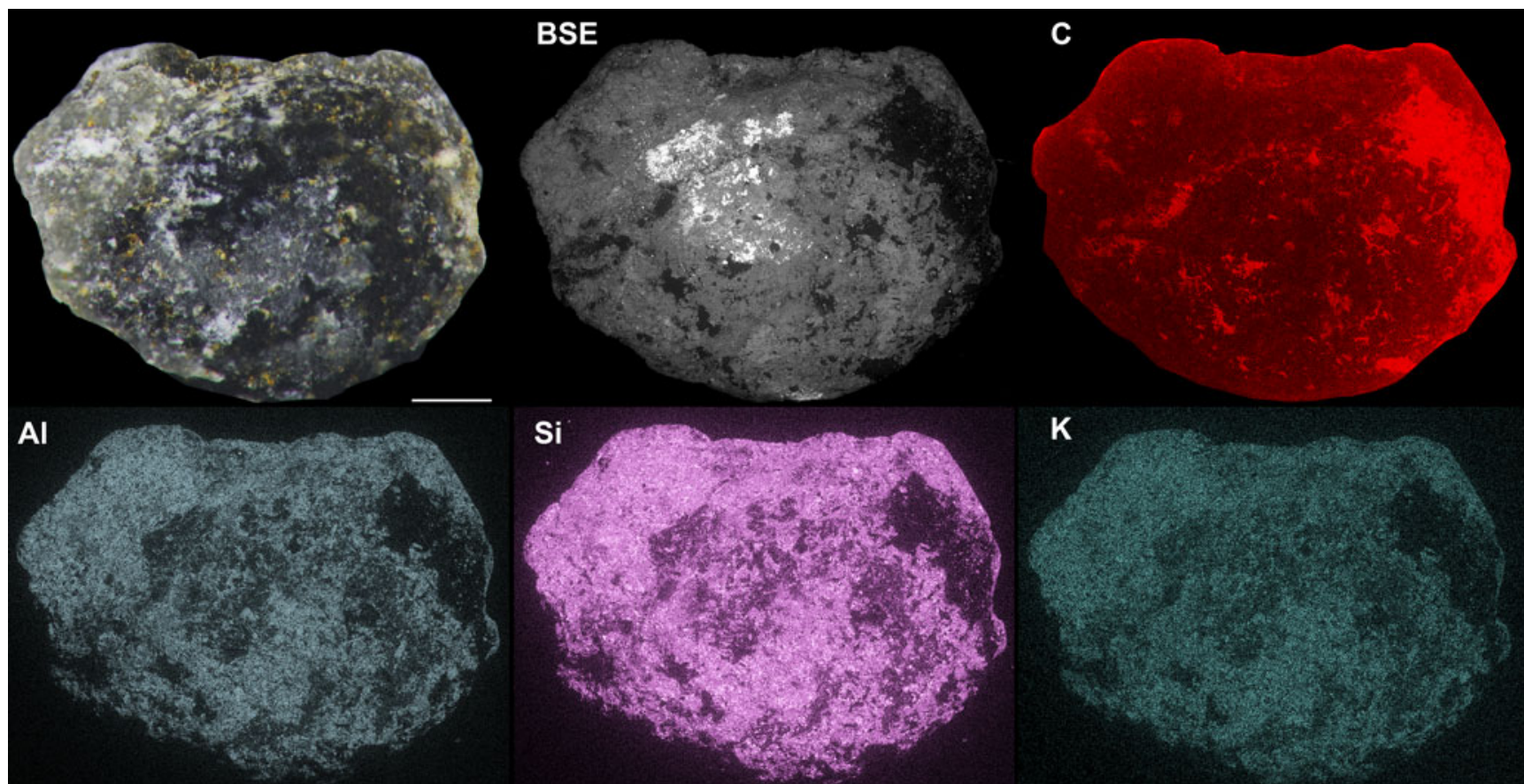

Mg

Ca

$\mathbf{P}$

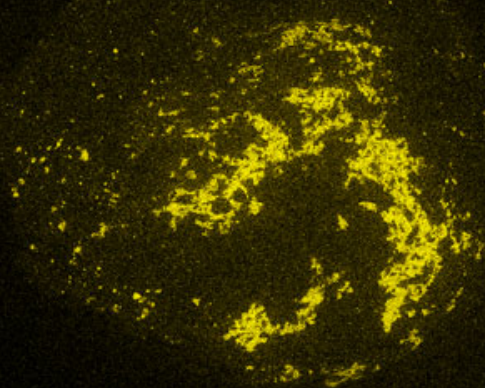

$\mathrm{Fe}$

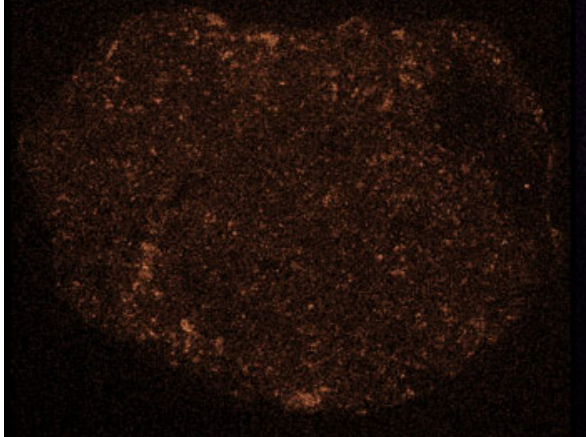

S

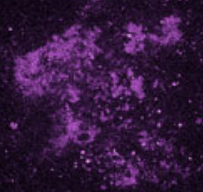

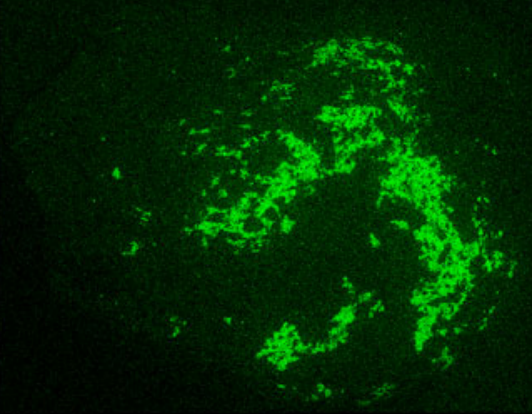

$\mathrm{Ba}$

Figure 3. SEM images of Egg One of Waptia cf. W. fieldensis, KUMIP 314302. Optical image under cross-polarized lighting (top left); Backscatter Electron (BSE) image (top middle); and composite image of elemental maps, brighter zones indicate greater enrichment of element (from top right to bottom right): $\mathrm{C}$, Al, $\mathrm{Si}$, $\mathrm{K}, \mathrm{Mg}$, $\mathrm{Ca}, \mathrm{P}, \mathrm{Fe}, \mathrm{S}, \mathrm{Ba}$. All images are scaled to be equal size. Scale bars represent $250 \mu \mathrm{m}$.

structures are most conservatively interpreted as voids, likely cracks that formed during compaction. The sub-vertical orientation and the distribution of these cracks are common features of differential compaction, as expected between a partially mineralized egg and the surrounding muddy sediments (e.g., Cowan and James, 1992). Unfortunately, there is no evidence of cleavage stages or a developing embryo in any of the eggs.

\section{Discussion}

Eggs of Waptia $c f$. W. fieldensis.-The combined SRXTM and EDS elemental analyses revealed two distinct phases within the eggs. The high-density phase is interpreted as pyrite, due to the overlapping distributions of $\mathrm{Fe}$ and $\mathrm{S}$ on the outer edges of the eggs, and the equant (cubic or triangular) outlines of many 


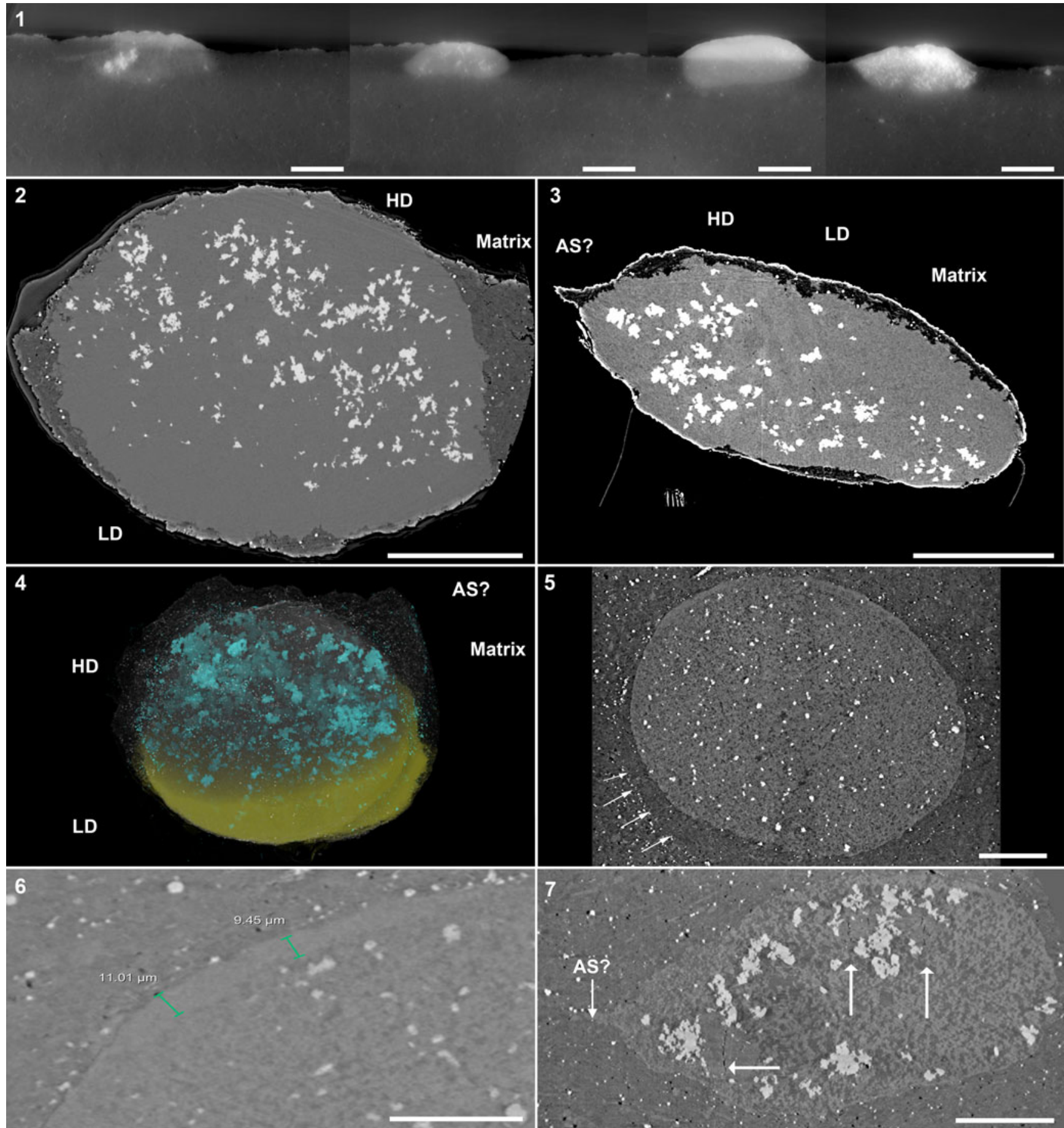

Figure 4. Lateral cross-sections of other three-dimensionally preserved eggs of Waptia cf. W. fieldensis (KUMIP 314032). For all eggs, the interior is brighter than the surrounding sediment. Difference in contrast is exaggerated using contrast thresholds within Dragonfly software. (1) A composite image showing the shape and mineralization of eggs in the host matrix. From left to right: Egg Two, Egg Five, Egg Four, and Egg Three. (2) Transverse cross-section of Egg One, showing two main mineralization phases and the matrix. Low-density phase is interpreted to be clay minerals and $\mathrm{CaCO}_{3}$, high-density phase is interpreted to be pyrite and a calcium phosphate mineral. (3) Lateral cross-section of Egg One, showing same structures as (2) and a potential attachment site of the egg to the adult. (4) Three-dimensional rendering of Egg One, showing the extent of mineralization found in $(\mathbf{2 , 3}$ ). Low-density phase is indicated on the lower half of the egg, high-density phase is indicated on the upper half, and matrix is made semi-transparent. (5) Transverse cross-section of Egg Four, showing the same mode of preservation in (2). Rectangle highlights potential preservation of an egg membrane or wall. Arrows show different preservation texture around the immediate vicinity of the egg and highlights potential jelly coating. (6) Close-up of potential egg membrane/wall in (5). Thickness varies along the margin, thinning towards the poles. Note homogenous texture of egg wall compared to the interior. (7) Lateral cross-section view of Egg Nine showing the distribution of sub-vertical cracks (white arrows) within the internal space, and potential attachment site. Abbreviations: $\mathrm{LD}=$ low density phase, $\mathrm{HD}=$ high density phase, as? = potential attachment site. Scale bars $=200 \mu \mathrm{m}(\mathbf{1}) ; 300 \mu \mathrm{m}$ $(\mathbf{2}, \mathbf{3}) ; 100 \mu \mathrm{m}(\mathbf{4}, \mathbf{5}, \mathbf{7}) ; 50 \mu \mathrm{m}(\mathbf{6})$. 
discrete crystals, which are often grouped into larger aggregates in the interiors (Figs. 3, 4.2-4.3). The low-density phase comprises the majority of the volume inside the eggs and appears brighter in the SRXTM data than the surrounding matrix. It is characterized by heterogeneity and the presence of relatively dark and light domains within the egg interiors (Fig. 4.4, 4.5). The EDS data clearly indicate the co-occurrence of $\mathrm{Ca}$ and $\mathrm{P}$, revealing the presence of calcium phosphate-likely hydroxyapatite-at the egg surface (Fig. 3). Given that calcium phosphate is a major mineralizing phase in eggs of Waptia fieldensis (Fig. 2.2; Caron and Vannier, 2016), we infer that the calcium phosphate phase observed at the surface extends into the egg interior, likely comprising the brighter portions within the darker, heterogeneous phase. The darker portions of the heterogeneous darker phase are similar to the matrix in SRXTM contrast and are interpreted as aluminosilicate sediment infill with micron-sized crystals of authigenic calcium carbonate (Fig. 3). The precipitation of a calcium phosphate mineral hints at mineralization of intra-egg organic matter, such as a developing embryo or remnant yolk content. This interpretation is supported by the observation that phosphorous concentration is higher in embryonic tissue than in yolks of modern marine arthropods (e.g., Hippler et al., 2012, fig. 3).

The phosphatization of selected soft tissues is a common authigenic mineralization pathway that occurs in BST fossils (Butterfield, 2002; Gaines et al., 2012), and decay experiments have also reported similar mineralization during the final stages of experiments (Hippler et al., 2012). Several decay experiments were successful in preserving carcasses and eggs in either $\mathrm{CaPO}_{4}, \mathrm{CaCO}_{3}$, or a combination of both (Martin et al., 2005; Gostling et al., 2008, 2009; Hippler et al., 2012). These decay experiments also showed that successful mineralization of invertebrate eggs was possible due to the preservation of outer-egg membranes. In the experiments, outer-egg membranes were preserved as a continuous outer surface or as remnants coated in mineralized bacteria (Martin et al., 2003; Hippler et al., 2012), $\mathrm{CaCO}_{3}$ (Briggs and Kear, 1993; Hippler et al., 2012), or fine mineral grains (Hippler et al., 2012). Fertilization envelopes and similar external structures provide physical barriers against microbial decay, as well as aid in maintaining an isolated microenvironment within the eggs, which is critical in the preservation of internal ultrastructures (Raff et al., 2006). However, the SRXTM data provide no evidence for an outer mineralized coating similar to that observed in decay experiments. This difference from decay experiments could reflect differences in the physical properties of modern arthropod eggs (modern arthropod eggs may be more physically robust than those of Waptia). Additionally, the main purpose of these decay experiments was to investigate the mineralization potential of eggs under specific conditions set by the experimenters, rather than investigating mineralization potential of eggs under conditions similar to those of the Cambrian Period. Therefore, the lack of mineralized coating observed on these eggs likely reflects different chemical conditions in comparison to modern decay experiments. Possible accessory structures, such as an attachment stalk (e.g., funiculus) or a jelly-like coating found in extant marine invertebrate eggs, were observed on the eggs of $W$. cf. W. fieldensis, but appeared highly degraded (Fig. 4.3, 4.4, 4.7; Martin et al., 2005), suggesting that these structures are prone to more rapid degradation than the yolk or embryo. Decay experiments have also shown that a lower phosphate-to-carbonate ratio could produce incomplete mineralization of invertebrate eggs relative to other tissues (Briggs and Kear, 1993; Hippler et al., 2012), which may reflect the gradient of egg preservation observed in W. cf. W. fieldensis. Given the abundance of carbonate in the matrix sediments of the Spence Shale and other BST deposits (Gaines et al., 2012), it seems likely that, outside of the eggs, the supply of carbonate greatly exceeded that of phosphate.

Decay experiments using the European lobster, Homarus gammarus (Linnaeus, 1758), also showed a gradient in mineralization of eggs that is comparable to that observed in the eggs of W. cf. W. fieldensis (Martin et al., 2005; Hippler et al., 2012). The Spence Shale specimen has only a few eggs that were preserved in high fidelity, with a clear delineation between the sediment matrix and the inner egg visible in the SRXTM data. The majority of the eggs appear highly degraded to the point that the sediment matrix and inner portions of eggs are difficult to differentiate using the SRXTM data. Variation in preservation may reflect the original concentrations of phosphorous within the yolks and the developing embryos prior to burial. Untreated crayfish eggs of Procambarus fallax f. virginalis (Hagen, 1870) exhibit uniform distributions of $P$ within the yolk and even greater enrichments of $\mathrm{P}$ within the embryonic tissue (Hippler et al., 2012, p. 1767, fig. 3B), which may have provided an adequate supply of dissolved phosphate for phosphatization. On the other hand, highly degraded waptiid eggs exhibit less internal phosphate mineralization and a higher degree of compaction, although far less that the degree of compaction observed in the unmineralized eggs preserved as carbonaceous compressions.

In addition to calcium phosphate, sulfate minerals were also observed on the surfaces of and within the eggs of W. cf. W. fieldensis in both EDS and SRXTM data. The surface of Egg One shows a patch of overlap in the elements $\mathrm{S}$ and $\mathrm{Ba}$ (Fig. 3), suggesting the presence of barite, which also occurs in vermiform fossils from the same locality at Miners Hollow (Broce and Schiffbauer, 2017, table 1). However, several lines of evidence suggest the brighter phase within the eggs are pyrite rather than barite: (1) the densities of pyrite and barite differ by 10\%, $5 \mathrm{~g} /$ $\mathrm{cm}^{3}$ and $4.48 \mathrm{~g} / \mathrm{cm}^{3}$, respectively (Teodorovich, 1961; Hanor, 2000), and the denser, higher-contrast phase corresponds to internal crystal aggregates and small crystals within the matrix, and does not correspond with the area that shows overlapping $\mathrm{S}$ and Ba in EDS spectra (Fig. 3); (2) soft-bodied fossils were preserved in anoxic microfacies within the Spence Shale (Garson et al., 2012), suggesting reducing conditions under which pyrite precipitation is facilitated by iron-and sulfate-reducing microbes (Farrell, 2014; Berg et al., 2020); and (3) marine barite forms under evaporative conditions, rather than the fully marine conditions under which the Spence Shale was deposited (Liddell et al., 1997). Barite precipitation may also be mediated by bacterial activity, but this process requires oxidizing conditions for cellular respiration, and barium that is derived from marine plankton (Griffith and Paytan, 2012). Together, these observations suggest that pyrite precipitation preceded barite formation, and barite was precipitated in a crack along the junction between the egg and matrix, long after fossilization and under completely different chemical circumstances, perhaps related to the 
Pleistocene pluvial history of the immediate region (Janecke and Oaks, 2011).

It is important to note that pyrite does not replicate any tissues or internal features of the eggs, but it is dispersed within the egg interiors. This example is quite distinct from pyritized trilobite eggs from the Ordovician Whetstone Gulf Formation, Lorrain Group, where framboidal and rare euhedral pyrite crystals replace the majority of inner egg spaces, and pyritization is the primary means by which morphology was captured (Hegna et al., 2017, p. 200, fig. 2E).

Pyritization of soft tissues is favored when organic-poor sediments focus the activities of iron and sulphate reduction around carcasses (Farrell, 2014) or mucous-lined burrows (Clark and Lutz, 1980). In the case of the waptiid eggs, small quantities of mostly micron-sized pyrite crystals were localized in the inner egg spaces and were more concentrated near the margins of the egg space. Similar pyrite formation was observed in Cambrian vermiform fossils, presumably influenced by the initial geometry of the organisms prior to decay and complete collapse (Broce and Schiffbauer, 2017). As such, the contrast between the inner and outer localization of pyrite may reflect the consequences of egg geometry and decay. It may be possible that pyrite nucleation was ubiquitous within the egg space during early taphonomic stages when the three-dimensionality was retained, but decay and subsequent compaction of the egg geometry resulted in aggregation of pyrite towards the edges while more inner crystals were less affected. Unfortunately, pyritization within the eggs did not capture clear outlines or other conspicuous remnants of developing embryos; rather, the concentration of pyrite within the eggs appears to correlate with the degree of compaction and/or degradation of the eggs. With increasing loss of structural integrity (i.e., greater levels of degradation), pyrite crystals were more abundant and uniformly dispersed within the internal egg space. Therefore, the degree of degradation of egg margins clearly influenced the supply of iron and sulfate to the interior of the eggs, and thus, the extent of pyrite precipitation.

Of the 18 eggs, at least seven are preserved as flat carbonaceous compressions, lacking in the classic three-dimensional shape, pyrite crystals, and outer phosphate preservation (Fig. 2.6, 2.7). Below, we explore the possibility that the specific circumstances that promoted carbonaceous preservation rather than internal mineralization of these eggs is related to early degradation of the egg membrane, which also appears to have influenced taphonomic variation observed within the threedimensionally preserved eggs.

Taphonomic history.-Data gathered in this study allow us to propose a taphonomic sequence that may have facilitated three-dimensional preservation of the eggs of $W$. cf. W. fieldensis. (1) Precipitation of a calcium phosphate mineral within the eggs suggests an acidic microenvironment and a high initial phosphorous concentration, likely provided by the embryo or yolk (Allison, 1988a). These conditions promoted phosphatization and inhibited carbonate precipitation (Sagemann et al., 1999). (2) At some point during decay, sediment matrix infiltrated the inner egg spaces, which, along with the calcium phosphate mineral phase, partly molded the original macromorphology of the eggs. (3) Infiltration of the sediment indicates a loss of structural integrity of the egg membrane, as also suggested by the SRXTM data (Fig. 4). Breach of the egg margin would have allowed for infiltration of fluids from outside the egg and disrupted the originally acidic microenvironment within the eggs, promoting carbonate and pyrite precipitation (Allison, 1988b; Briggs, 2003; Martin et al., 2005; Broce and Schiffbauer, 2017). (4) Degradation of the egg membrane and the differing concentrations of phosphate minerals and sediment inside the eggs would have led to different degrees of compaction. Eggs with a greater extent of phosphatization would have had greater structural integrity, and thus, experienced only minimal compaction. Those with little to no calcium phosphate suffered moderate to extreme compaction. (5) Precipitation of barium sulfate along a crack at the surface of at least one of the eggs sometime after the Cambrian.

These observations beg the question: why were some eggs mineralized, while others within the same clutch that were preserved as carbonaceous compressions were not? The precipitation of calcium phosphate requires microenvironmental conditions quite different from those of the sediments that enclosed them, namely lower $\mathrm{pH}$ and an internal source of $\mathrm{P}$ (Briggs and Wilby, 1996; Sagemann et al., 1999; Butterfield, 2002; Martin et al., 2003; Skawina, 2010; Gaines, 2014). Within phosphatized eggs associated with this specimen, a gradient in extent of mineralization is recognized that correlates with preservation of the egg membrane, and, by inference, with the relative timing of decay of that feature. We hypothesize that the difference between carbonized and phosphatized eggs may reflect an end member of the same gradient, specifically reflecting egg margins that were breached during or shortly after burial, precluding the development of microenvironments inside the eggs favorable to phosphatization and resulting in preservation as carbonaceous compressions. Early rupture of egg walls may have been physically induced, during burial, or via microbial activity during decay. While it is possible that differences in egg composition (i.e., differing developmental stages) or in the early burial environment (e.g., eggs preserved under the carapace vs. outside of it) may have regulated the considerable differences in taphonomic expression observed, it is an intriguing possibility that the full range of variation may have been controlled by the relative timing of the rupture of the egg margins.

Comparison to Waptia fieldensis. - The egg clutch discussed here shares similar characteristics with Waptia fieldensis from the Burgess Shale (Caron and Vannier, 2016). Both egg clutches are located in the antero-dorsal region of the adult body, and in the inner carapace space, which is interpreted as the brooding chamber (Caron and Vannier, 2016). The egg clutch of $W$. cf. W. fieldensis is preserved more distal to the body than in W. fieldensis, which may suggest a shifting of the cluster position post-mortem.

Both $W$. cf. W. fieldensis and W. fieldensis have similar clutch sizes, with $W$. cf. W. fieldensis having $\sim 18$, and W. fieldensis having an average clutch size of 10.4 across five specimens (Caron and Vannier, 2016, p. 72, table 1). It is noteworthy that dorsoventrally preserved $W$. fieldensis specimens showed equal preservation of eggs on each side, potentially up to a maximum of 24 eggs per adult (Caron and Vannier, 
2016). However, the lateral preservation of W. cf. W. fieldensis from the Spence Shale and the lack of other egg-brooding waptiid specimens cannot provide unequivocal information on its maximum clutch size. Differences in body size and carapace length may offer an explanation for the variation in clutch size. Increased body size and carapace length may offer greater physical brooding space for the egg clutch, allowing for higher fecundity for crustaceans (Shakuntala, 1977; Pavanelli et al., 2008). The W. cf. W. fieldensis specimen is larger than the Burgess Shale specimens, with a total body length reaching $\sim 7.8 \mathrm{~cm}$, while Burgess Shale specimens reached an average of $5.4 \mathrm{~cm}$ total body length (Caron and Vannier, 2016, p. 72, table 1). The carapace of $W$. cf. $W$. fieldensis was highly degraded and was unable to be compared with the Burgess Shale specimens. In contrast, a recent report of egg clusters in Chuandianella ovata ( $\mathrm{Li}, 1975)$ of the Cambrian Chengjiang biota recorded up to 50 ovooids preserved from a $2.25 \mathrm{~cm}$ specimen (Ou et al., 2020, table 1). This discovery may suggest that, although carapace length and body size may affect clutch size, differences in reproductive strategies of the species may contribute more to determining clutch size (Ou et al., 2020).

In W. cf. W. fieldensis, the average egg diameter of the clutch is $\sim 0.96 \mathrm{~mm}$ (Table 1), which is within the range of average egg diameters observed in $W$. fieldensis $(0.69-2.4 \mathrm{~mm})$ across the five published specimens (Caron and Vannier, 2016, p. 72, table 1). In both the Spence Shale and Burgess Shale specimens, egg size and shape varied within the same individuals, presumably reflecting taphonomic biases and differences in the stages of embryonic development among the eggs (Caron and Vannier, 2016). Non-fertilized eggs and recently extruded eggs are found to be more spherical in decapods (Alwes and Scholtz, 2006; Pavanelli et al., 2008), and throughout embryogenesis, eggs increase in size and become more elliptical due to the changes in osmotic pressure created by developing embryos (Rosa et al., 2003; Winnicki et al., 2004). This process also coincides with a weakening of the egg membrane, which compensates for the increasing egg volume and size (Winnicki et al., 2004). Chuandianella ovata from the Chengjiang biota bears similar morphological features with the waptiid specimens from the Spence Shale and Burgess Shale, yet the average egg diameter is much smaller in comparison $(0.489-0.554 \mathrm{~mm})$ and the clutch size of $C$. ovata is much larger, reflecting different reproductive methods (Ou et al., 2020, p. 3, table. 1).

Comparison of Burgess Shale type (BST) and Spence Shale preservation.-The Spence Shale specimen appears to have followed the typical pathway for BST preservation, where organic decay was strongly inhibited by rapid burial under presumably anoxic or weakly oxygenated conditions, resulting in preservation of organic remains as carbonaceous compressions (Gaines et al., 2012; Gaines, 2014). However, there are some key differences in the biostratinomic settings of the Burgess Shale and the Spence Shale specimens.

First, the physical depositional setting between Burgess Shale and Spence Shale differs greatly. The Burgess Shale is associated with the Cathedral Escarpment, which effectively promoted entrainment of organisms in sediment-gravity flows, brief downslope transportation, and rapid burial in claystone sediments under anoxic conditions (Gaines, 2014). By contrast, the Spence Shale was deposited across a lower-relief slope (Liddell et al., 1997) that limited the capacity for transportation of organisms across the chemocline compared to the steeper depositional slope immediately adjacent to the Burgess Shale (Gaines, 2014). Accordingly, many of the exceptionally preserved fossils of the Spence Shale represent molts or partially decomposed specimens (Gaines et al., 2012), which fit the description of the body fossil of $W$. cf. W. fieldensis.

Although soft-bodied fossils are most abundant in beds lacking bioturbation (i.e., anoxic conditions) at both localities, the Spence Shale exhibits higher frequency redox fluctuations than yet documented in the Burgess Shale, indicating that the Spence Shale was deposited on the boundary of a fluctuating oxycline (Garson et al., 2012; Kloss et al., 2015). Thus, the Spence Shale may have represented a paleoenvironment in which BST preservation was intermittently viable, rather than optimal (Garson et al., 2012).

\section{Conclusion}

This report of Waptia cf. W. fieldensis from the Spence Shale, Utah, provides unique evidence of variable preservation of eggs in a single clutch in situ, namely phosphatization and carbonaceous compression. Volumetric renderings show two prominent primary phases in the three-dimensionally preserved eggs: a brighter and denser phase that corresponds with pyrite, and a darker and heterogeneous phase interpreted as a calcium phosphate mineral plus infiltrating host sediment. No discernable embryonic development within the eggs was identified, but a possible egg membrane ultrastructure was identified. The co-occurrence of phosphatization and carbonaceous compression may reflect differences in microenvironmental conditions and/or developmental stages among the eggs; however, we hypothesize that the relative timing of eggmargin breach controlled the distribution of taphonomic pathways across the clutch, with rupture at or near the time of burial leading to carbonaceous preservation and later rupture facilitating mineralization in isolated microenvironments inside the eggs. This report demonstrates that combining EDS elemental analysis and SRXTM imaging provides an ideal dataset for interpreting three-dimensionally preserved BST fossils because presence or absence of key elements from EDS analysis allows for identification and validation of phases in SRXTM images. Therefore, both analyses are complementary and provide an opportunity for a more holistic understanding of preservation, with a wide range of potential applications within paleontology.

\section{Acknowledgments}

We thank J. Kimmig and an anonymous reviewer for their insightful comments. The synchrotron analysis and interpretations were undertaken by J. Moon in an independent undergraduate research course (Research Studies in Ecology and Evolutionary Biology [EEB497H1S]) at the University of Toronto under the supervision of J.-B. Caron. We also thank S. Lackie at the University of Windsor for assisting in the collection of EDS data. We also thank the European Synchrotron 
Radiation Facility for providing the time to use beamline ID19 (Project ES-664), in particular, P. Tafforeau for the initial tests and V. Fernandez for conducting the final analyses using the beamline ID19. We thank B.S. Lieberman and J. Kimmig for their assistance with the Utah collections at the University of Kansas. This work would not have been possible without funding from the Embassy of France in Ottawa, National Sciences and Engineering Council Discovery grant number 341944, and funding from the Royal Ontario Museum to J.-B. Caron. We also thank S. Scharf for providing editorial suggestions on an earlier version of this manuscript.

\section{Data availability statement}

Data available from the Dryad Digital Repository: https://doi. org/10.5061/dryad.0zpc866xv.

\section{References}

Allison, P.A., 1988a, Konservat-Lagerstätten: cause and classification: Paleobiology, v. 14, p. 331-344.

Allison, P.A., 1988b, The role of anoxia in the decay and mineralization of proteinaceous macro-fossils: Paleobiology, v. 14, p. 139-154.

Alwes, F., and Scholtz, G., 2006, Stages and other aspects of the embryology of the parthenogenetic Marmorkrebs (Decapoda, Reptantia, Astacida): Development Genes and Evolution, v. 216, p. 169-184.

Babcock, L.E., and Robison, R.A, 1988, Taxonomy and paleobiology of some middle Cambrian Scenella (Cnidaria) and Hyolithids (Mollusca) from western North America: University of Kansas Paleontological Contributions, v. 121 , p. $1-22$.

Bengtson, S., and Zhao, Y., 1997, Fossilized metazoan embryos from the earliest Cambrian: Science, v. 277, p. 1645-1648.

Berg, J.S., Duverger, A., Cordier, L., Laberty-Robert, C., Guyot, F., and Miot, J., 2020, Rapid pyritization in the presence of a sulfur/sulfate-reducing bacterial consortium: Scientific Reports, v. 10, 8264. https://doi.org/10.1038/ s41598-020-64990-6.

Briggs, D.E.G., 2003, The role of decay and mineralization in the preservation of soft-bodied fossils: Annual Reviews of Earth and Planetary Sciences, v. 31 , p. $275-301$.

Briggs, D.E.G., and Kear, A.J., 1993, Fossilization of soft tissues in the laboratory: Science, v. 259, p. 1439-1442.

Briggs, D.E.G., and McMahon, S., 2016, The role of experiments in investigating the taphonomy of exceptional preservation: Palaeontology, v. 59, p. 1-11.

Briggs, D.E.G., and Wilby, P.R., 1996, The role of the calcium carbonatecalcium phosphate switch in the mineralization of soft-bodied fossils: Journal of the Geological Society, London, v. 153, p. 665-668.

Briggs, D.E.G., Lieberman, B.S., Hendricks, J.R., Halgedahl, S.L., and Jarrard, R.D., 2008, Middle Cambrian arthropods from Utah: Journal of Paleontology, v. 82 , p. $238-254$.

Broce, J.S., and Schiffbauer, J.D., 2017, Taphonomic analysis of Cambrian vermiform fossils of Utah and Nevada, and implications for the chemistry of Burgess Shale-type preservation: Palaios, v. 32, p. 600-619.

Butterfield, N.J., 2002, Leanchoilia guts and the interpretation of threedimensional structures in Burgess Shale-type fossils: Paleobiology, v. 28, p. $155-171$.

Butterfield, N.J., 2003, Exceptional fossil preservation and the Cambrian Explosion: Integrative and Comparative Biology, v. 43, p. 166-177.

Caron, J.-B., and Vannier, J., 2016, Waptia and the diversification of brood care in early arthropods: Current Biology, v. 26, p. 69-74.

Cheng, G., Peng, F., Duan, B., and Dong, X., 2011, Internal structure of Cambrian fossil embryo Markuelia revealed in the light of synchrotron radiation X-ray tomographic microscopy: Acta Geologica Sinica, v. 85, p. 81-90.

Clark, G.R., and Lutz, R.A., 1980, Pyritization in the shells of living bivalves: Geology, v. 8, p. 268-271.

Conway Morris, S., and Robison, R.A., 1988, More soft-bodied animals and algae from the middle Cambrian of Utah and British Columbia: University of Kansas Paleontological Contributions, v. 122, p. 1-48.

Conway Morris, S., Selden, P.A., Gunther, G., Jamison, P.G., and Robison, R.A., 2015, New records of Burgess Shale-type taxa from the middle Cambrian of Utah: Journal of Paleontology, v. 89, p. 411-423.

Cowan, C.A., and James, N.P., 1992, Diastasis cracks: mechanically generated synaeresis-like cracks in upper Cambrian shallow water oolite and ribbon carbonates: Sedimentology, v. 39, p. 1101-1118.
Dong, X.-P., Cunningham, J.A., Bengtson, S., Thomas, C.-W., Liu, J., Stampanoni, M., and Donoghue, P.C.J., 2013, Embryos, polyps and medusae of the early Cambrian scyphozoan Olivooides: Proceedings of the Royal Society B, v. 280, e20130071. https://doi.org/10.1098/rspb.2013.0071.

Donoghue, P.C.J., Bengtson, S., Dong, X.-P., Gostling, N.J., Huldtgren, T., Cunningham, J.A., Yin, C., Yue, Z., Peng, F., and Stampanoni, M., 2006a, Synchrotron X-ray tomographic microscopy of fossil embryos: Nature, v. 422, p. 680-683.

Donoghue, P.C.J., Kouchinsky, A., Waloszek, D., Bengtson, S., Dong, X.-P., Val'kov, A.K., Cunningham, J.A., and Repetski, J.E., 2006b, Fossilized embryos are widespread but the record is temporally and taxonomically biased: Evolution \& Development, v. 8, p. 232-238.

Dornbos, S.Q., 2011, Phosphatization through the Phanerozoic, in Allison, P.A., and Bottjer, D.J., eds., Taphonomy: Process and Bias Through Time: Amsterdam, Springer Netherlands, p. 436-453.

Duan, Y., Han, J., Fu, D., Zhang, X., Yang, X., Komiya, T., and Shu, D., 2014, Reproductive strategy of the bradoriid arthropod Kunmingella douvillei from the lower Cambrian Chengjiang Lagerstätte, South China: Gondwana Research, v. 25, p. 983-990.

Eriksson, M.E., Terfelt, F., Elofsson, R., Maas, A., Marone, F., Lindskog, A., Waloszek, D., Schmitz, B., and Stampanoni, M., 2016, Baring it all: undressing Cambrian 'Orsten' phosphatocopine crustaceans using synchrotron radiation X-ray tomographic microscopy: Lethaia, v. 49, p. 312-326.

Farrell, Ú.C., 2014, Pyritization of soft tissues in the fossil record: an overview, in Laflamme, M., Schiffbauer, J.D., and Darroch, S.A.F., eds., Reading and Writing of the Fossil Record: Preservational Pathways to Exceptional Fossilization: The Paleontological Society Papers, v. 20, p. 35-58.

Foster, J.R., and Gaines, R. R., 2016, Taphonomy and paleoecology of the "middle" Cambrian (Series 3) formations in Utah's west desert: recent finds and new data, in Comer, J.B., Inkenbrandt, P.C., Krahulec, K.A., and Pinnell, M.L., eds., Resources and Geology of Utah's West Desert: Utah Geological Association Publication, v. 45, p. 291-336.

Gaines, R.R., 2014, Burgess Shale-type preservation and its distribution in space and time, in Laflamme, M., Schiffbauer, J.D., and Darroch, S.A.F., eds., Reading and Writing of the Fossil Record: Preservational Pathways to Exceptional Fossilization: The Paleontological Society Papers, v. 20, p. $123-146$.

Gaines, R.R., and Droser, M.L., 2005, New approaches to understanding the mechanics of Burgess Shale-type deposits: from the micron scale to the global picture: The Sedimentary Record, v. 3, p. 4-8.

Gaines, R.R., Briggs, D.E.G., and Zhao, Y., 2008, Cambrian Burgess Shaletype deposits share a common mode of fossilization: Geology, v. 36, p. 755-758.

Gaines, R.R., Hammarlund, E.U., Hou, X., Qi. C., Gabbott, S.E., Zhao, Y., Peng, J., and Canfield, D.E., 2012, Mechanism for Burgess Shale-type preservation: Proceedings of the National Academy of Sciences, v. 109, p. 51805184. https://doi.org/10.1073/pnas.1111784109.

Garson, D.E., Gaines, R.R., Droser, M.L., Liddell, W.D., and Sappenfield, A., 2012, Dynamic palaeoredox and exceptional preservation in the Cambrian Spence Shale of Utah: Lethaia, v. 45, p. 164-177.

Gostling, N.J., Thomas, C.-W., Greenwood, J.M., Dong, X., Bengtson, S., Raff, E.C., Raff., R.A., Degnan, B.M., Stampanoni, M., and Donoghue, P.C.J., 2008, Deciphering the fossil record of early bilaterian embryonic development in light of experimental taphonomy: Evolution \& Development, v. 10, p. 339-349.

Gostling, N.J., Dong, X., and Donoghue, P.C.J., 2009, Ontogeny and taphonomy: an experimental taphonomy study of the development of the brine shrimp Artemia salina: Palaeontology, v. 52, p. 169-186.

Griffith, E.M., and Paytan, A., 2012, Barite in the ocean-occurrence, geochemistry and palaeoceanographic applications: Sedimentology, v. 59, p. $1817-1835$.

Hagen, H.A., 1870, Monograph of the North American Astacidae: Illustrated Catalogue of the Museum of Comparative Zoology at Harvard College, v. 3, 109 p.

Hammersburg, S.R., Hasiotis, S.T., and Robison, R.A., 2018, Ichnotaxonomy of the Cambrian Spence Shale Member of the Langston Formation, Wellsville Mountains, Northern Utah, USA: Paleontological Contributions, v. 20, p. $1-66$.

Han, J., Kubota, S., Li, G., Yao, X., Yang, X., Shu, D., Li, Y., Kinoshita, S., Sasaki, O., Komiya, T., and Yan, G., 2013, Early Cambrian pentamerous cubozoan embryos from South China: PLoS ONE, v. 8, e70741. https:// doi.org/10.1371/journal.pone.0070741.

Hanor, J. S., 2000, Barite-Celestine geochemistry and environments of formation: Reviews in Mineralogy and Geochemistry, v. 40, p. 193-275.

Hegna, T.A., Martin, M.J., and Darroch, S.A.F., 2017, Pyritized in situ trilobite eggs from the Ordovician of New York (Lorraine Group): implications for trilobite reproductive biology: Geology, v. 45, p. 199-202.

Hippler, D., Hu, N., Steiner, M., Scholtz, G., and Franz, G., 2012, Experimental mineralization of crustacean eggs: new implications for the fossilization of Precambrian-Cambrian embryos: Biogeosciences, v. 9, p. 1765-1775. 
Janecke, S.U., and Oaks, R.Q., 2011, New insights into the outlet conditions of late Pleistocene Lake Bonneville, southeastern Idaho, USA: Geosphere, v. 7, 1369-1391.

Kimmig, J., and Selden, P.A., 2020, A new shell-bearing organism from the Cambrian Spence Shale of Utah: Palaeoworld, v. 30, p. 220-228. https:// doi.org/10.1016/j.palwor.2020.05.003.

Kimmig, J., and Strotz, L.C., 2017, Coprolites in mid-Cambrian (Series 2-3) Burgess Shale-type deposits of Nevada and Utah and their ecological implications: Bulletin of Geosciences, v. 92, p. 297-309.

Kimmig, J., Strotz, L.C., Kimmig, S.R., Egenhoff, S.O., and Lieberman, B.S., 2019, The Spence Shale Lagerstätte: an important window into Cambrian biodiversity: Journal of the Geological Society, v. 176, p. 609-619.

Kloss, T.J., Dornbos, S.Q., Chen, J.-Y., McHenry, L.J., and Marenco, P.J., 2015, High-resolution geochemical evidence for oxic bottom waters in three Cambrian Burgess Shale-type deposits: Paleogeography, Paleoclimatology, Paleoecology, v. 440, p. 90-95.

Li, Y.W., 1975, On the Cambrian Ostracoda with new materials from Sichuan, Yunnan, and southern Shaanxi, China: Professional Papers of Stratigraphy and Palaeontology, v. 2, p. 37-72.

Liddell, W.D., Wright, S.H., and Brett, C.E., 1997, Sequence stratigraphy and paleoecology of the middle Cambrian Spence Shale in northern Utah and southern Idaho, in Link, P.K., and Kowallis, B.J., eds., Proterozoic to Recent Stratigraphic Tectonics and Volcanology, Utah, Nevada, Southern Idaho and Central Mexico: Brigham Young University Geology Studies, v. 42, p. 59-78.

Lin, J.-P., Scott, A.C., Li, C.-W., Wu, H.-J., Ausich, W.I., Zhao, Y.-L., and Hwu, Y.-K., 2006, Silicified egg clusters from a middle Cambrian Burgess Shaletype deposit, Guizhou, South China: Geology, v. 34, p. 1037-1040.

Linnaeus, C., 1758, Systema Naturæ per regna tria naturæ, secundum classes, ordines, genera, species, cum characteribus, differentiis, synonymis locis. Tomus I. Editio decima, reformata: Holmiæ [=Stockholm], Laurentius Salvius, $824 \mathrm{p}$.

Martin, D., Briggs, D.E.G., and Parkes, R.J., 2003, Experimental mineralization of invertebrate eggs and the preservation of Neoproterozoic embryos: Geology, v. 31, p. 39-42.

Martin, D., Briggs, D.E.G., and Parkes, R.J., 2005, Decay and mineralization of invertebrate eggs: Palaios, v. 20, p. 562-572.

Muscente, A.D., Hawkins, A.D., and Xiao, S., 2015, Fossil preservation through phosphatization and silicification in the Ediacaran Doushantuo Formation (South China): a comparative synthesis: Palaeogeography, Palaeoclimatology, Palaeoecology, v. 434, p. 46-62.

Object Research Systems (ORS) Inc., 2021, Dragonfly 2021.1 [Computer software]: Montreal, Canada. https://www.theobjects.com/dragonfly/index.html [April 2021].

Ou, Q., Vannier, J., Yang, X., Chen, A., Mai, H., Shu, D., Han, J., Fu, D., Wang, R., and Mayer, G., 2020, Evolutionary trade-off in reproduction of Cambrian arthropods: Science Advances, v. 6, eaaz3376. https://doi.org/10. 1126/sciadv.aaz3376.

Pavanelli, C.A.M., Mossolin, E.C., and Mantelatto, F.L., 2008, Reproductive strategy of the snapping shrimp Alpheus armillatus H. Milne-Edwards, 1837 in the South Atlantic: fecundity, egg features, and reproductive output: Invertebrate Reproduction and Development, v. 52, p. 123-130.

Raff, E.C., Villinski, J.T., Rudolf Turner, F., Donoghue, P.C.J., and Raff, R.A., 2006, Experimental taphonomy shows the feasibility of fossil embryos: Proceedings of the National Academy of Sciences, v. 103, p. 5846-5851.

Rigby, J.K., 1980, The new middle Cambrian sponge Vauxia magna from the Spence Shale of northern Utah and taxonomic position of the Vauxiidae: Journal of Paleontology, v. 54, p. 234-240.

Robison, R.A., 1969, Annelids from the middle Cambrian Spence Shale of Utah: Journal of Paleontology, v. 43, p. 1169-1173.

Robison, R.A., Babcock, L.E., and Gunther, V.G., 2015, Exceptional Cambrian fossils from Utah: a window into the age of trilobites: Utah Geological Survey Miscellaneous Publications, v. 15, p. 1-97.
Rosa, R., Morais, S., Calado, R., Narciso, L., and Nunes, M.L., 2003, Biochemical changes during the embryonic development of Norway lobster, Nephrops norvegicus: Aquaculture, v. 221, p. 507-522.

Sagemann, J., Bale, S.J., Briggs, D.E.G., and Parkes, R.J., 1999, Controls on the formation of authigenic minerals in association with decaying organic matter: an experimental approach: Geochimica et Cosmochimica Acta, v. 63, p. $1083-1095$.

Schiffbauer, J.D., Xiao, S., Cai, Y., Wallace, A.F., Hua, H., Hunter, J., Xu, H., Peng, Y., and Kaufman, A.J., 2014, A unifying model for NeoproterozoicPalaeozoic exceptional fossil preservation through pyritization and carbonaceous compression: Nature Communications, v. 5, 5754. https://doi.org/10. 1038/ncomms6754.

Schindelin, J., Arganda-Carreras, I., Frise, E., Kaynig, V., Longair, M., et al., 2012, Fiji: an open-source platform for biological image analysis: Nature Methods, v. 9, p. 676-682. https://doi.org/10.1038/nmeth.2019.

Shakuntala, K., 1977, The relation between body size and number of eggs in the freshwater prawn, Macrobrachium lamarrei (H. Milne Edwards) (Decapoda, Caridea): Crustaceana, v. 33, p. 17-22.

Siveter, D.J., Tanaka, G., Farrell, Ú.C., Martin, M.J., Siveter, D.J., and Briggs, D.E.G., 2014, Exceptionally preserved 450-million-year-old Ordovician ostracods with brood care: Current Biology, v. 24, p. 801-806.

Skawina, A., 2010, Experimental decay of gills in freshwater bivalves as a key to understanding their preservation in Upper Triassic lacustrine deposits: Palaios, v. 25, p. 215-220.

Stampanoni, M., Borchert, G., Wyss, P., Abela, R., Patterson, B., Hunt, S., Vermeulen, D., and Rüegsegger, P., 2002, High resolution X-ray detector for synchrotron-based microtomography: Nuclear Instruments and Methods in Physics Research A, v. 491, p. 291-301.

Sutton, M.D., 2008, Tomographic techniques for the study of exceptionally preserved fossils: Proceedings of the Royal Society B, v. 275, p. 1587-1593.

Teodorovich, G. I., 1961, Authigenic Minerals in Sedimentary Rocks: New York, Springer US, 120 p.

Vannier, J., Aria, C., Taylor, R.S., and Caron, J.-B., 2018, Waptia fieldensis Walcott, a mandibulate arthropod from the middle Cambrian Burgess Shale: Royal Society Open Science, v. 5, 172206. https://doi.org/10.1098/ rsos. 172206.

Walcott, C.D., 1912, Cambrian Geology and Paleontology II. No. 6. Middle Cambrian Branchiopoda, Malacostraca, Trilobita and Merostomata: Smithsonian Miscellaneous Collections, v. 57, p. 145-228.

Whitaker, A.F., and Kimmig, J, 2020, Anthropologically introduced biases in natural history collections, with a case study on the invertebrate paleontology collections from the middle Cambrian Spence Shale Lagerstätte: Palaeontologia Electronica, v. 23, a58. https://doi.org/10.26879/1106.

Whitaker, A.F., Jamison, P.G., Schiffbauer, J.D., and Kimmig, J, 2020 , Re-description of the Spence Shale palaeoscolecids in light of new morphological features with comments on paleoscolecid taxonomy and taphonomy: Paläontologische Zeitschrift, v. 94, p. 661-674.

Winnicki, A., Pawlos, D., Formicki, K., and Smietana, P., 2004, On selected morphomechanical characteristics of signal crayfish (Pacifastacus leniusculus Dana) eggs during incubation: Bulletin Francais de la Pêche et de la Pisciculture, v. 372-373, p. 431-438.

Yin, Z., Zhu, M., Bottjer, D.J., Zhao, F., and Tafforeau, P., 2016, Meroblastic cleavage identifies some Ediacaran Doushantuo (China) embryo-like fossils as metazoans: Geology, v. 44, p. 735-738.

Zhang, X.-G., and Pratt, B.R., 1994, Middle Cambrian arthropod embryos with blastomeres: Science, v. 266, p. 637-639.

Zhang, X.-G., Pratt, B.R., and Shen, C., 2011, Embryonic development of a middle Cambrian (500 myr old) scalidophoran worm: Journal of Paleontology, v. 85, p. 898-903.

Accepted: 23 July 2021 